\title{
Depletion gilding, innovation and life-histories: the changing colours of Nahuange metalwork
}

Juanita Sáenz-Samper ${ }^{1} \&$ Marcos Martinón-Torres ${ }^{2, *}$

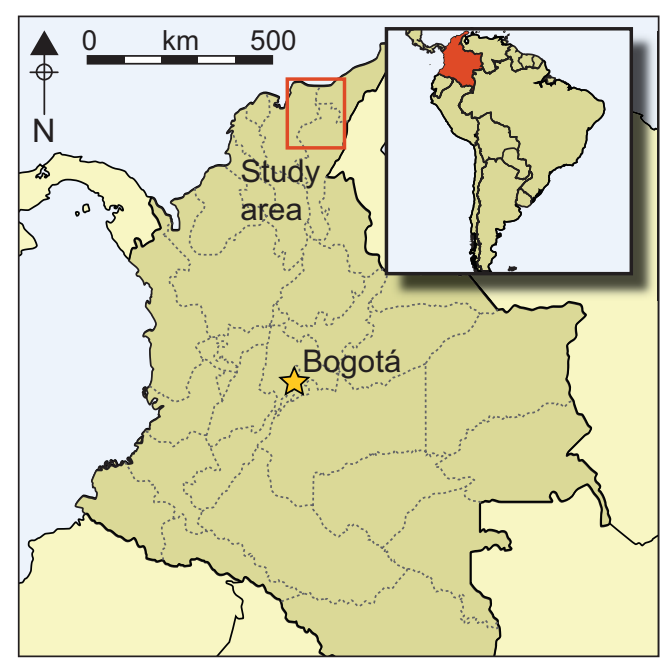

The technique of depletion gilding is well evidenced in pre-Columbian Andean gold work. Artefacts from the Nabuange period in Colombia (c. AD 100-1000) were subject to metallographic, chemical and microscopic analyses to provide regional comparative data on metalworking traditions. Results suggest that depletion gilding may have been an accidental discovery and, contrary to widespread assumptions, not always a desirable feature. This research illustrates how technological innovation may not always be immediately adopted, and considers how the life-history of gold artefacts may affect their appearance and microstructure. It also offers directions for future studies of depletion gilding elsewhere.

Keywords: South America, Colombia, pre-Columbian, archaeometallurgy, depletion gilding, gold, life-histories

\section{Introduction}

Pre-Columbian goldsmiths of South America are renowned for having developed, among many other technical feats, a range of gilding techniques that rendered their objects golden, even if the quantity of gold in the bulk metal was relatively low. A variety of gilding methods are known that are predominant in different regions, depending on individual goldsmithing traditions. Gilding techniques can be broadly categorised into those that functioned by adding a gold layer on top of a different metal substrate (with subvariants, such as fusion, leaf-gilding or electrochemical plating), and those that involved removing copper (and, sometimes, silver) from the surface of a gold-copper-silver alloy (named 'tumbaga'),

1 Museo del Oro, Banco de la República, Calle 16 \#5-41, Bogotá DC, Colombia

2 Institute of Archaeology, University College London, 31-34 Gordon Square, London WC1H OPY, UK

* Author for correspondence (Email: m.martinon-torres@ucl.ac.uk) 
leaving it more gold-rich and hence more golden in colour than the substrate (e.g. Scott 1983; Lechtman 1988; La Niece \& Meeks 2000). The latter repertoire of techniques is broadly known as 'depletion gilding', and it was favoured in large regions of the Andes, including parts of present-day Colombia. Heather Lechtman's pioneering research helped in understanding the technical sophistication of depletion-gilding techniques; she also proposed interpretive models to explain this particular cultural choice (Lechtman 1973, 1977, 1984, 1988).

Essentially, depletion gilding is achieved by exposing a gold-copper-silver alloy to an oxidising environment, which leads to the formation of copper oxide scales on the surface. During removal of these oxides by burnishing or pickling with plant acids, copper is progressively removed from the surface of the alloy, and silver and gold replace it. By repeating the process several times, metalsmiths achieved remarkably golden (and gold-rich) surfaces, even if the bulk alloy was relatively gold-poor. The thickness of the golden layer could be as thin as $10 \mu \mathrm{m}$ or less, but it was sufficient to alter the appearance of the objects radically. As Lechtman posited, this process probably responded not so much to a concern with saving metals or reducing their melting temperatures, but rather to a cultural norm dictating that the golden 'essence' of the metal must be exhibited on the objects' surfaces. Thus, depletion gilding became a key element of the Andean 'technical style' that straddles material and symbolic considerations, and it has continued to be recognised as such (e.g. González 2004).

While overarching models are useful to drive the discipline, higher-resolution regional studies often reveal idiosyncratic practices that do not fit easily into those paradigms. Here, we present the first analytical characterisation of Nahuange gold work from Colombiaa metallurgical tradition that developed in the northern Sierra Nevada de Santa Marta, based on copper-rich tumbaga alloys. Of particular significance is the discovery that goldsmiths often obtained depleted-gilded surfaces unintentionally, but these surfaces were painstakingly polished off to remove the golden layer and reveal the pinkish hue of the bulk alloy. Similar features were also found on some objects that had been gilded deliberately. The singularity of this tradition has implications for our understanding of the discovery of depletion gilding as a technique, the role of social agents in the acceptance or rejection of technological innovations, the complex life-histories of metal objects, the concept of value and the diachronic development of Colombian gold-working traditions.

\section{Background to Nahuange metalwork}

The Sierra Nevada de Santa Marta is a pyramid-shaped mountain range close to the Caribbean coast of Colombia. It is over $5700 \mathrm{~m}$ in height, with steep slopes that descend directly to alluvial plains to the west, the sea to the north, and with a range of arid plains and river valleys to the east and south. The mountain range therefore encompasses a wide range of climates and ecological niches in a relatively small area. Although it is a very prominent element of the landscape, it was not an impassable barrier, and allowed the movement of people and ideas (Figure 1).

Archaeologically, the region is best known for the Tairona culture, which has been documented through excavations at famous sites, such as Ciudad Perdida and Pueblito.

(C) Antiquity Publications Ltd, 2017 


\section{Depletion gilding, innovation and life-histories}

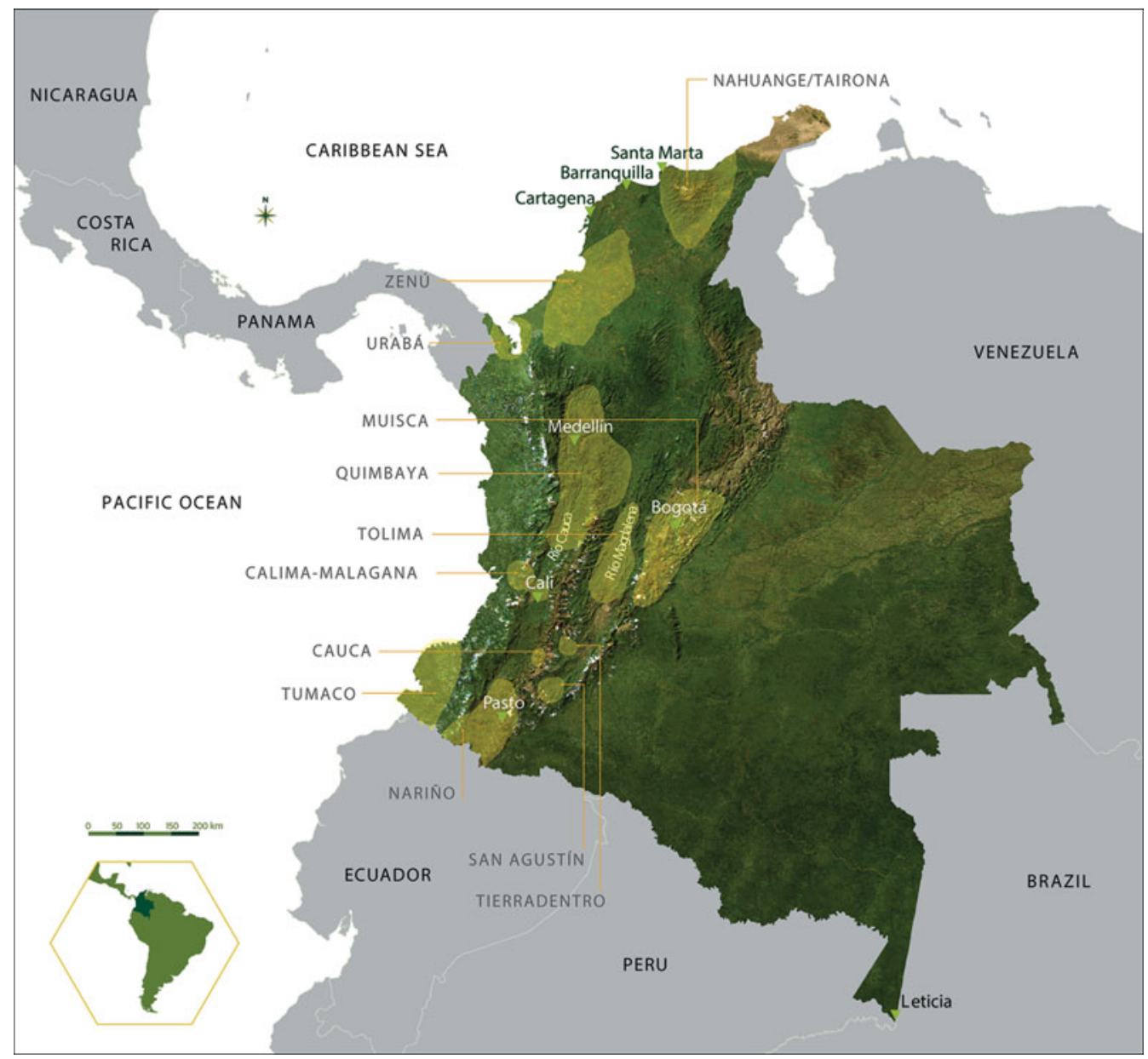

Figure 1. Map of Colombia indicating the main gold-working regions. The geographic span of the Nahuange coincides with the Tairona in the Sierra Nevada de Santa Marta, near the Caribbean coast.

Tairona material culture is most conspicuously evidenced by thousands of gold-alloy artefacts preserved at the Museo del Oro in Bogotá. Research has begun, however, to reveal an earlier phase at several Tairona sites, with different habitation structures and characteristic material culture. This phase, broadly dated to $c$. AD 100-1000, is known as the Early or Nahuange Period-named after the bay where J. Alden Mason excavated a large tomb in 1922 (Mason 1931, 1936, 1939; Bischof 1969; Bray 2003). Further research is necessary to characterise the societies of the Nahuange Period and their sociocultural development. The scarce Nahuange archaeological evidence indicates that villages appear to be spread primarily towards the Caribbean coast, associated with bays or valleys. Recent archaeological investigations have, however, revealed that Nahuange villages were also scattered up in the hills. Nahuange pottery has, for example, been found in the lower strata of Tairona terrace foundations at Pueblito and Ciudad Perdida (Giraldo 2010). Nahuange subsistence activities included agriculture and fishing. The complexity 
of the pottery, lapidary work and gold work suggests the existence of craft specialists. Little is known concerning the political or religious structure of Nahuange communities, although the rich tomb of Nahuange perhaps suggests some social inequality (Bray 2003; Langebaek 2005). It has been suggested that social and political change occurring around the tenth century $\mathrm{AD}$ led to the demographic growth and increasing political centralisation that seem characteristic of the Tairona (Oyuela-Caycedo 1987; Langebaek 2005; Giraldo 2010).

Nahuange material culture is only beginning to be understood. Studies so far have revealed cultural influences from several regions that were developed idiosyncratically. The morphology and iconography of Nahuange pottery share traits with ceramics recovered from the valleys of the Ranchería River in the Guajira, the Magdalena River and the Caribbean Plains (Falchetti 1987; Langebaek 1987; Oyuela-Caycedo 1987; Bray 1990, 2003). Winged plaques and female figurines carved in green stones may be local manifestations of motifs that are widely documented in Venezuela, Aruba, the Sierra Nevada del Cocuy, the Caribbean Plains of Colombia, the Caribbean and the Isthmus (Plazas 2007).

Defining Nahuange gold work is one aim of an ongoing project led by Juanita SáenzSamper (2015). A major challenge is the scarcity of well-documented archaeological contexts for many of these artefacts. Furthermore, the morphological traits shared by Nahuange and Tairona metal artefacts, which are indicative of cultural continuities, can sometimes complicate the phasing of such artefacts. It is becoming possible, however, to characterise some specific traits of the Nahuange tradition by referring to metal objects that can be dated by association to datable material culture, or whose charcoal-rich cores can be dated directly by radiocarbon (as was the case of one tumbaga figurine recovered at the eponymous tomb of Nahuange, dated to AD 427-536 (OxA 1577 at $95.4 \%$ confidence); date modelled in OxCal 4.1, using IntCal13 calibration curve; Bronk Ramsey 2009; Reimer et al. 2013)—(cf. Falchetti 1987; Bray 2003; Sáenz-Samper 2015). In general, while ceramics are indicative of connections with the east, the typology and iconography of gold work compare strongly with artefacts from cultures of the interior, particularly the Early Quimbaya and Early Zenú of the middle Cauca Valley and the Caribbean Plains (Falchetti 1993).

Nahuange gold work was predominantly used for body adornment and display. Common typologies include pectorals (especially double-spiral, circular, triangular or ornitomorphic), pendants (mainly anthropomorphic, ornitomorphic, frog- and feline-shaped, or triangular), nose pendants (rhomboidal, elliptical, triangular or semilunar, among others), ear pendants, flat discs, belts/diadems and bracelets. Decorative motifs include spirals, volutes, circles, dotted lines, and schematic representations of birds and other animals. Although relatively flat objects predominate, three-dimensional figurative pendants cast by the lost-wax technique are also common-especially in the form of birds, frogs and quadrupeds with a raised tail (Figure 2) (Sáenz-Samper 2015). A more detailed discussion of the problems and potentials of defining the Nahuange culture, its origins, broader connections and evolution will be addressed in later publications. We concentrate here on the technical analysis of artefacts that are probably attributable to the Nahuange period. The aim is to provide an initial approach to understanding the materials and technologies that (C) Antiquity Publications Ltd, 2017 


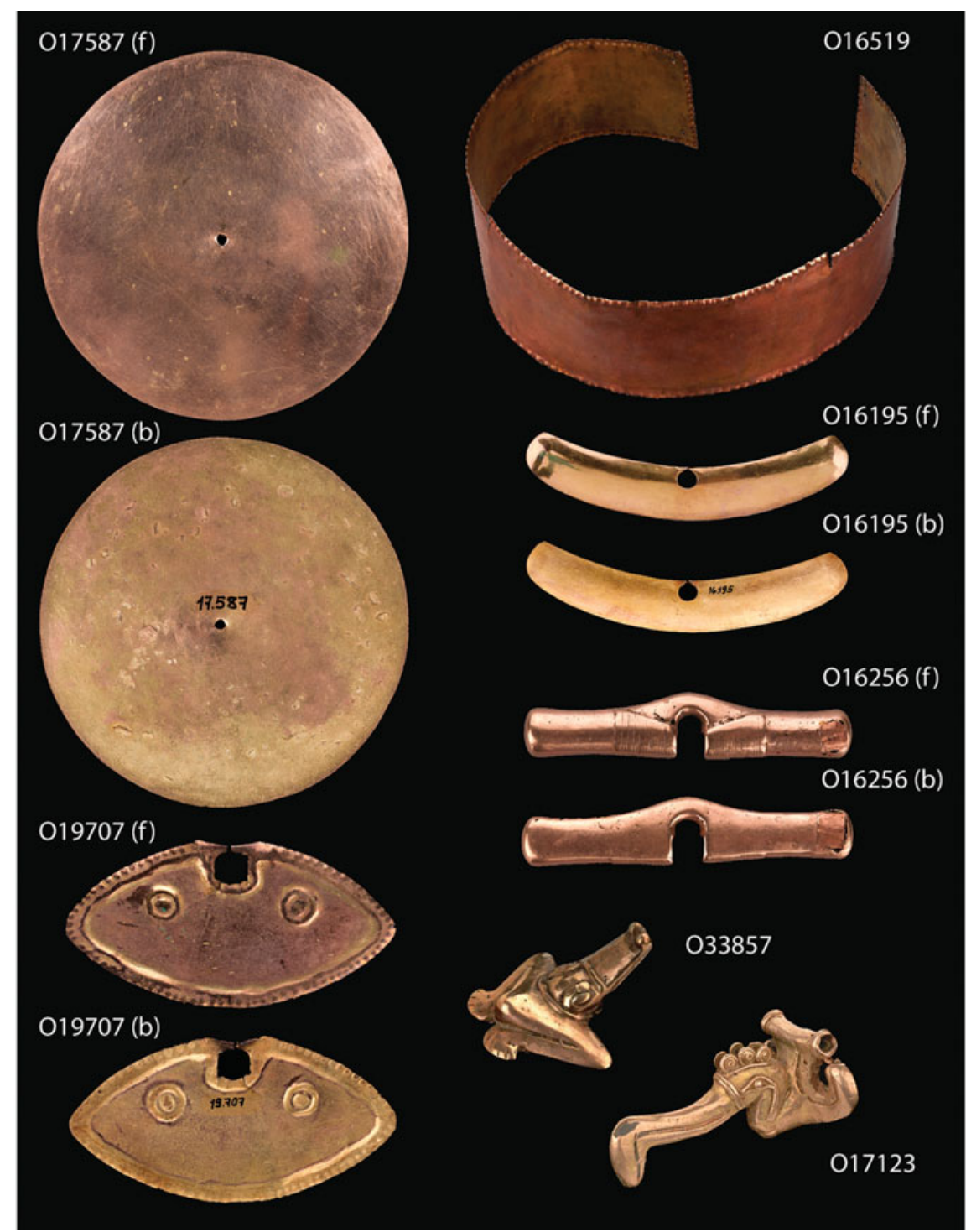

Figure 2. Examples of Nahuange metal artefacts. On hammered objects, note the difference between the highly polished, pinkish front surfaces (f) and the unpolished, yellow, matt back surfaces (b). Not to scale. All photographs by Clark Manuel Rodríguez, Museo del Oro, Banco de la República. Main dimensions in centimetres: O16519-H: $6 \times$ W: 51.8; O16195-H: $2.3 \times$ W: 13.4; O16256-H: $1.6 \times W: 7.6 ; 019707-H: 4.3 \times W: 8.3 ; O 33857-H: 6.7 \times W: 6.2 ; O 17123-H: 2.6 \times W: 5.6 ; 017587-$ D: 10 .

characterise Nahuange metalwork, as a basis for future comparisons with the later Tairona and other traditions. Particular emphasis is placed on surface treatment techniques, as these are shown to be among the most idiosyncratic and prompt further analytical consideration of archaeological gold work. 


\section{Analytical methods}

All the artefacts studied belong to the public collections held at the Museo del Oro in Bogotá. Within a broader analysis of Nahuange and Tairona artefacts, 44 complete and fragmentary Nahuange objects were examined visually and under low-power digital microscopy to assess morphology and surface texture. Several analytical techniques were employed to characterise manufacturing traits of the objects. Optical, digital and scanning electron microscopy (SEM) of whole artefacts or fragments were used to identify traces of the tools and the techniques employed in surface polishing and decoration. Metallography, scanning electron microscopy-energy dispersive spectrometry (SEM-EDS) and wavelength dispersive electron microprobe (EPMA) analyses of polished cross-sections provided further information about the microstructure and hence the artefact-manufacturing sequence. Particular attention was paid to the possible existence of surface layers, and their microstructure and composition, in comparison to the main body of the objects. In addition to those samples analysed chemically by SEM-EDS and EPMA, non-invasive analyses of a number of objects were carried out by portable X-ray fluorescence spectrometry (pXRF). These results were combined with those of previous (unpublished) surface XRF analyses (both on surfaces and cross-sections) undertaken by the Departamento Técnico Industrial (DTI) of the Banco de la República de Colombia (Sáenz-Samper 2015). New invasive analyses were performed at the UCL Institute of Archaeology; surface analyses (low-power digital microscopy and chemical) were conducted both at UCL in London and at the Museo del Oro in Bogotá (see online supplementary material (OSM)). All compositional values reported here are in percentage by weight $(\%)$.

\section{Results}

\section{Visual and microscopic examination}

A large proportion of Nahuange metal artefacts are flat ornaments made on thin sheets (mean thickness $207 \mu \mathrm{m}$, median $118 \mu \mathrm{m}, \mathrm{n}=5$ ). Their slight curvature, together with the presence and arrangement of decoration, facilitates identification of their fronts and backs. Most objects show a very shiny, highly polished, pinkish front surface, which contrasts with a matt, scaly, yellower back surface (Figures $2 \& 3$ ). Microscopic examination helps visualise the extremely fine polishing marks on the pink surfaces. In some cases, the high density, straightness and parallel arrangement of these polishing marks suggest the use of a rotary polishing device - an issue requiring further investigation, especially considering the lack of rotary kinetic energy use in pottery making and transport in this region (Sáenz-Samper 2015). High-magnification surface imaging also allows inferences concerning the techniques and tools employed for decoration. Here, chiselled, chased and punched forms predominate, as occasionally evidenced by the ragged profile of the chiselled lines and the metal displacement caused by punching and embossing (Figure 4). Microscopic examination also shows remnants of a more yellow surface layer on the pink surfaces. These are typically confined to corners and crevices that would have been harder to polish, or to the inside part of the narrower chiselled decoration lines (Figures 4 \& 5). These features indicate that during their manufacture or later life-history (and following (C) Antiquity Publications Ltd, 2017 


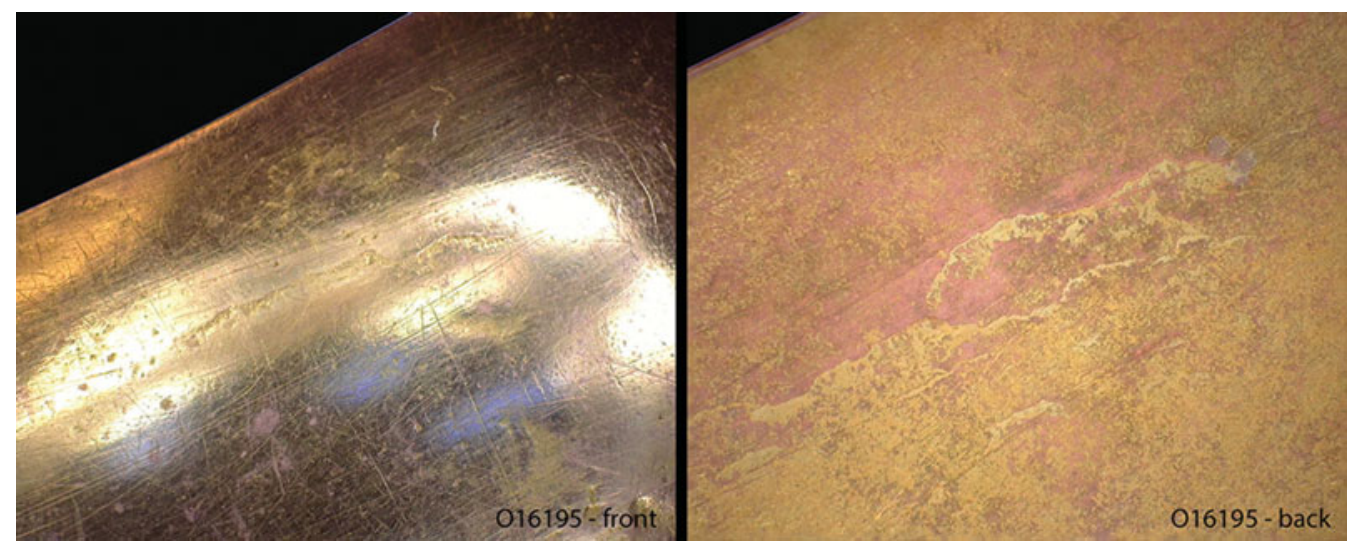

Figure 3. Comparison between the highly polished front surface and the matt, unpolished back surface of nose ornament O16195. Photographs by Marcos Martinón-Torres.

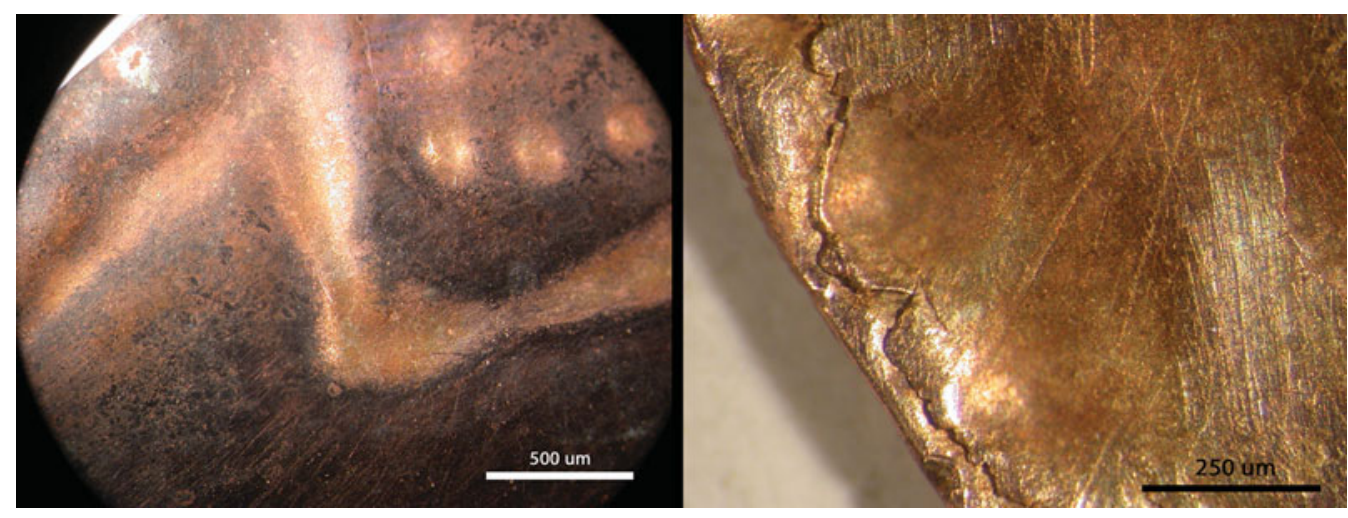

Figure 4. Details of decoration on metal artefacts. Left) detail of the punched and chased decoration on the front surface of nose ornament 018155 , showing remnants of a more golden colour inside the depression. Right) detail of metal displaced by the punched decoration on the back of nose ornament O19259. Photographs by Juanita Sáenz-Samper.

decoration), some of these objects were fully covered by a golden layer, and that this was later removed from their fronts by polishing.

Three-dimensional cast artefacts are generally pink or orange all over, and exhibit different degrees of polishing (Figure 2). They are often cast using a variant of the lostwax technique that involved the use of thick cores, made of a fine, charcoal-rich material, inside the wax model. After casting, this core remains exposed through openings on the back or bottom of the metal artefacts. These objects also include occasional pseudofiligree spirals or other details that were modelled with wax threads and cast as part of the artefact. Although pink shades predominate, some cast objects also show remnants of what seems to have been a more golden surface layer that was subsequently polished off. These gilding remnants are typically confined to the crevices between object bodies and their applied decoration (Figure 6), although in a few cases they appear to cover the bulk of the object.

(C) Antiquity Publications Ltd, 2017 


\section{Cross-section and chemical analyses}

SEM-EDS and EPMA results show the use of gold-copper-silver (Au-Cu-Ag) alloys of varied compositions, but always rather copper-rich (EPMA results: mean $\pm S D \mathrm{Cu}$

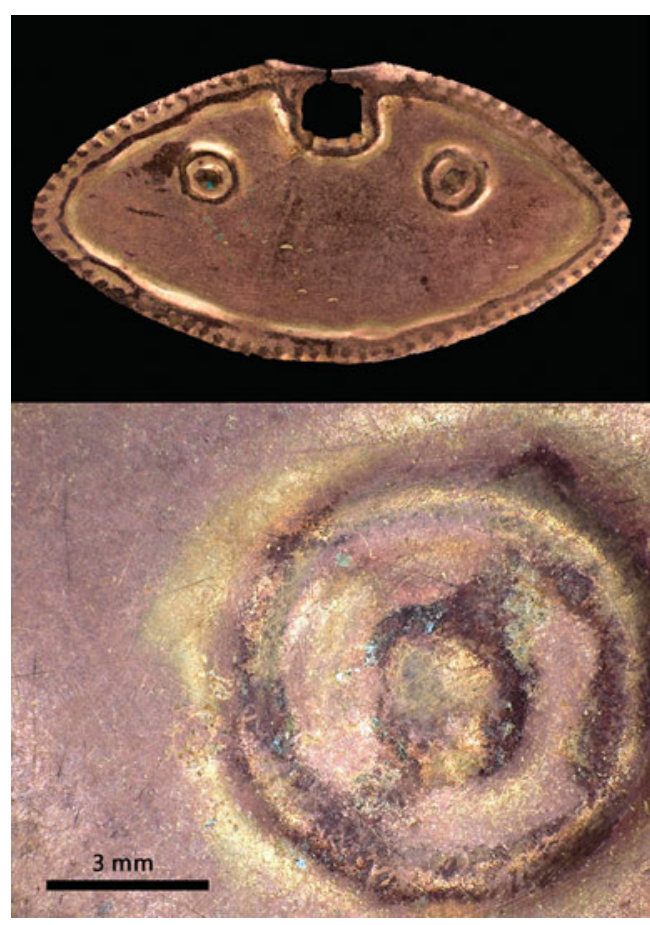

Figure 5. Front view of hammered nose ornament 019707 and detail of the raised decoration, showing remnants of the golden layer that once covered the whole surface. Object dimensions: $4.3 \times 8.3 \mathrm{~cm}$. Photograph by Clark Manuel Rodríguez, Museo del Oro, Banco de la República; detail by Marcos Martinón-Torres. $62.9 \pm 9.5 \%$, Ag $5.6 \pm 1.2 \%$, Au $30.4 \pm$ $7.8 \% ; \mathrm{n}=5)$. While there is no evidence for pre-Hispanic silver-extraction technology in the area, an abundance of naturally argentiferous gold in Colombia is well known. We infer, therefore, that these alloys were made by combining metallic copper with argentiferous gold, rather than alloying three separate metals. All other elements are present in concentrations lower than $0.03 \%$, and hence near the detection limits of the EPMA (SáenzSamper 2015). Most interesting, however, are the chemical and microstructural gradients observed when some artefacts were examined in cross-section. The back surfaces of flat objects frequently show a very thin and porous layer that is much richer in gold than the substrate, similar to those reported elsewhere as resulting from depletion gilding (Figures $7 \& 8$ ) (e.g. Lechtman 1988; Hörz \& Kallfas 2000; Schlosser et al. 2012). This layer is sometimes found on the front surfaces too; here, it is thinner and often discontinuous, and barely perceptible when the object is seen from the surface (maximum layer thickness on front $2.0 \pm 1.6 \mu \mathrm{m}$, mean layer thickness on back $4.2 \pm 0.8 \mu \mathrm{m}$, based on two measurements per layer on five objects). Consistent gilded surfaces on both sides are seen in only a very few cases. These observations appear to support the proposition that many objects would have been wholly covered by gilding, but that the golden layer was often removed from the front surfaces. The single cast object that we analysed in cross-section did not show any traces of a gilded layer.

Cross-section analyses also showed the metallographic structure of the objects. Flat artefacts display a tight, fibrous texture resulting from intense hammering; intergranular corrosion reveals small recrystallised grains that denote episodes of heating between hammering cycles, to ensure the alloy retained its malleability (Figure 7). The cast object analysed metallographically showed a dendritic structure, indicating the lack of mechanical work after casting. 


\section{Depletion gilding, innovation and life-histories}

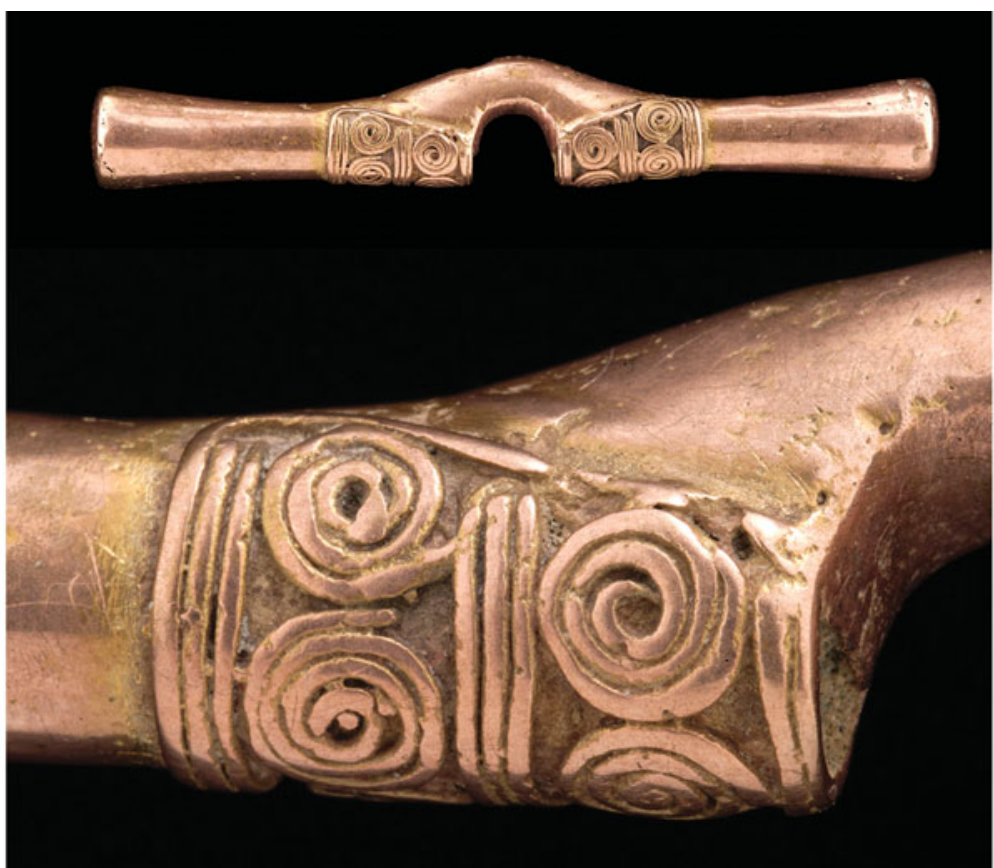

Figure 6. Front view of cast nose ornament 018124 and detail of the pseudofiligree decoration, showing remnants of the golden layer that once covered the whole surface. Photographs by Clark Manuel Rodriguez, Museo del Oro, Banco de la República.

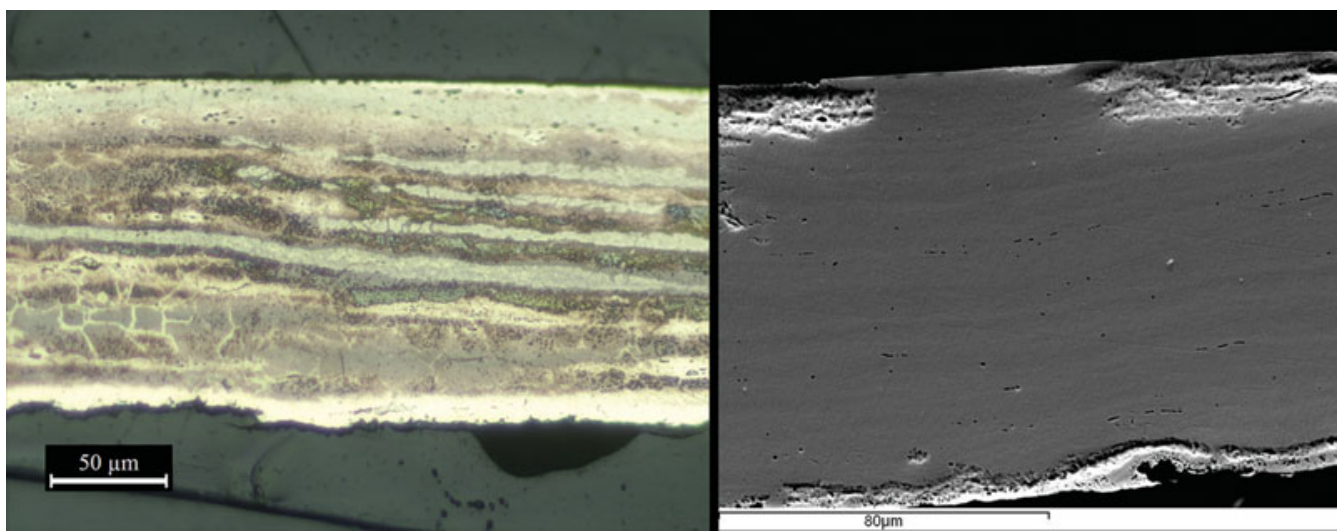

Figure 7. Polished cross-sections of hammered objects 016196 (left image: optical microscope, etched in alcoholic ferric chloride) and O26820b (right image: SEM secondary electron image). Note the straight surface on the front (top of the images), resulting from intense polishing, compared to the porous, golden layer on the back (bottom). The cavities are the result of corrosion. The metallographic image on the left also shows the fibrous texture resulting from intense hammering, as well as the recrystallisation achieved by annealing. Photographs by Nohora Alba Bustamante and Juanita Sáenz-Samper.

We carried out non-invasive pXRF analyses of a larger number of objects to compare alloy choices between flat, hammered objects and three-dimensional cast ones, and pooled these new analyses with legacy data (overall mean \pm SD: $\mathrm{Cu} 52.4 \pm 15.9 \%, \mathrm{Ag} 7.4 \pm 3.2 \%$, Au $39.9 \pm 13.9 \%$; $n=36$; see OSM). Figure 9 confirms that, for all types of object, preferred

(C) Antiquity Publications Ltd, 2017 


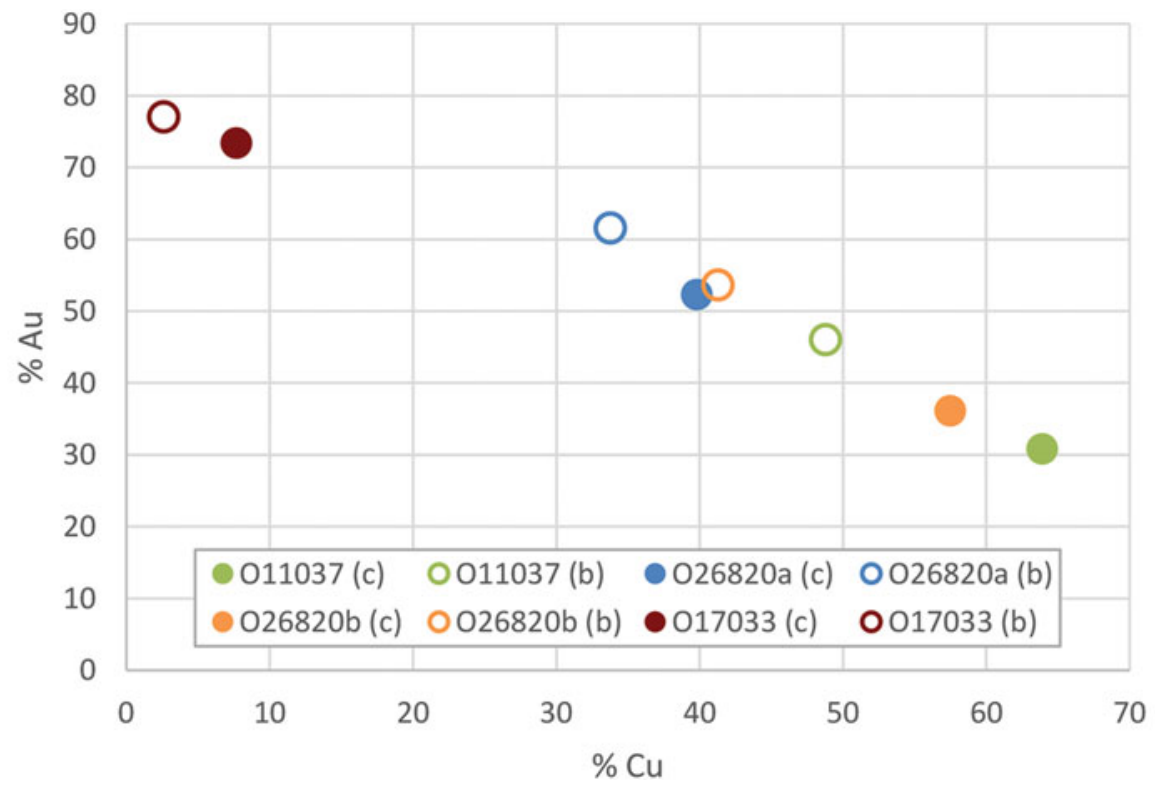

Figure 8. Scatterplot comparing the gold and copper levels on the core (c: full circles) and back layer (b: empty circles) in four hammered Nahuange artefacts, as measured by SEM-EDS on metallographic sections. Note the higher gold levels on the back surfaces, compared to the bulk.

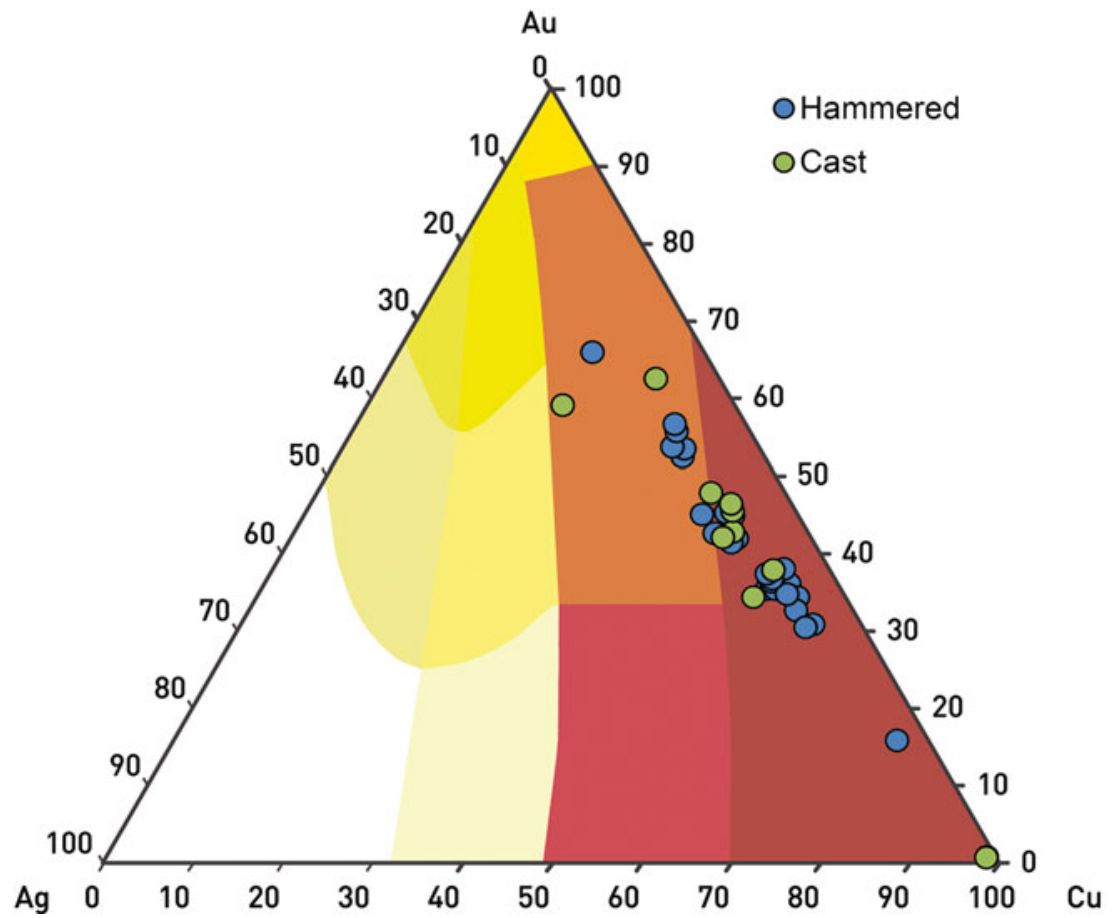

Figure 9. Plot of the chemical composition of Nahuange metal artefacts on a ternary colour diagram, using normalised values in percentage by weight (\%). See OSM for data.

(C) Antiquity Publications Ltd, 2017 
alloys were those with relatively high proportions of copper, corresponding with pinkish and orange colours. No significant compositional differences were found between cast and hammered artefacts (the fact that the two artefacts of nominally pure copper are cast may simply reflect a sampling bias). When the XRF results, as measured from the back and front of the same hammered objects, are compared, the back analyses tend to show higher gold levels. But this is not always the case, and the differences are much smaller than what might be expected, considering the very noticeable contrasts in colour between back and front surfaces. This may be explained by the exceptional thinness of the gilded back layer (mean $4.2 \pm 0.8 \mu \mathrm{m}$ ) and its inherent porosity, meaning that much of the X-ray fluorescence detected is produced beneath this layer (effective X-ray-penetration depth in a gold alloy is around $10 \mu \mathrm{m}$ for $\mathrm{Cu} \mathrm{K} \alpha$, and higher for $\mathrm{Ag} \mathrm{K} \alpha$ and $\mathrm{Au} \mathrm{L} \alpha$; cf. Gigante et al. 2005; Troalen et al. 2014). This comparison demonstrates that non-invasive XRF may provide a reliable indication of bulk major element concentrations in gold alloys, even when surface phenomena are present (cf. Blakelock 2016).

\section{Discussion}

Visual examination of Nahuange gold work reveals a preference for pinkish hues and highly polished surfaces. Microscopic analysis, however, shows that often these surfaces had been previously covered by a gilded layer, which was subsequently removed from the visible side of these objects. We propose that, in many of these cases, depletion gilding was an inevitable side effect of the manufacturing sequence by hammering and annealing copperrich tumbagas. Crucially, however, this golden appearance would not always be desired. This would explain why the front surfaces of diadems, breast plates and nose rings were meticulously polished to return them to their former pink colour. The removal of the gilding is not consistent with use-wear: the polish is generally too thorough and uniform, appearing only on the front of objects (the front being less exposed to use-wear through contact with the individual wearing the object).

Heather Lechtman has previously proposed that depletion gilding could have been discovered by accident during the hammering work with tumbagas. As regular reheating was required to avoid fracture of the metal, smiths would have realised the progressive deposition of dark (copper oxide) scales on the surfaces. When removed, these would leave a more yellow appearance. In her own words, "there [was] essentially no way of preventing it" (Lechtman 1988: 354). This would have led to subsequent experimentation to optimise the method and apply it to cast objects. It has typically been assumed that this would have been an advantageous and desirable discovery, in that it required less gold and, more importantly, connected with broader Andean value systems as manifest in the symbolism of gold and copper. Our study has confirmed the association between depletion gilding and early hammered tumbagas at Sierra Nevada de Santa Marta, and hence supports Lechtman's model of discovery. It has also demonstrated, however, that golden surfaces were not always immediately and preferentially accepted. If metals indeed had 'essences' to be displayed on the surface of artefacts, then the preferred essence for display was not always that of gold.

The uptake and popularisation of depletion gilding in Sierra Nevada de Santa Marta did not take place until the Tairona period-approximately seven centuries after our 
documented earliest evidence of 'polished off depletion gilding. This observation reminds us that even though a technological discovery can occur by accident, its widespread adoption does not-it requires a suitable social context in which the innovation may fulfil a utilitarian or cultural role. Nevertheless, the situation seems more complex than a wholesale rejection of depletion gilding in the Nahuange period, followed by a full adoption of the technique by the Tairona. Potentially contradicting this scenario are the few hammered objects from which the gilding was not removed and, especially, the cast objects with patches of gilding remnants. In the latter, the gilding is hard to explain as unintentional, as neither hammering nor annealing would have been required during manufacture; both the gilding and the subsequent 'ungilding' may represent deliberate practice.

To explain this diversity, a more detailed consideration of artefact life-histories may be required. It is possible that the removal of the golden layer did not take place immediately after manufacture. It may have been carried out at a later stage of the object's life, perhaps as part of a ritual or to mark a particular moment in the life of an individual or the community. Similarly, the gilding (and subsequent polishing) of cast objects may represent different stages in the social life of the object, rather than all taking place at the beginning. The signs of extensive wear shown by some of these artefacts are compatible with relatively long life-histories of moderately intense use, which may have involved more than one person.

Ana María Falchetti $(1999,2003)$ has investigated the symbolism of metals in indigenous American societies, in which metal is often associated with ideas of transformation and the continuity of life. The yellow colour of gold, its immortality and incorruptibility are often connected with the male power of the sun, whereas the various reddish hues of copper and its capacity for transformation (through corrosion or other colour-changing processes) prompt associations with the human life-course. Among the present-day Desana people of Vaupés in south-east Colombia, different hues of red are classified as copper-like and are related to female properties, to the corruptible and mortal essence of human flesh and blood (as opposed to the bones; Reichel-Dolmatoff 1981). Against this background, and notwithstanding the risks of using ethnographic parallels, we propose that the colour and sheen of Nahuange metal objects may have been adjusted in the course of their life-histories. Intentional alteration may, for example, have been carried out prior to deposition in a funerary context, where the removal of the gilded layer may have represented a form of 'ritual killing'. This is perhaps comparable to the case of a Nahuange pectoral at the Museo del Oro collection that was clearly folded before deposition, and also to similar practices documented elsewhere. This hypothesis could be tested by comparing the funerary $v$ s nonfunerary find contexts for Nahuange artefacts-a task made difficult by the scarcity of well-defined contexts. Another plausible scenario would be the alteration of the artefacts to mark important moments in life, such as the owner attaining puberty. Considering recurrent associations between reddish colours and females, it may be useful to investigate further the possible connections between women and metalwork. It may be significant that human representations in Nahuange metal, stone and ceramic artefacts are predominantly female.

A related question pertains to the origins and spread of this particular tradition of metal surface alterations. A small number of early Quimbaya artefacts (500 BC-600 AD; UribeVillegas 2005) appear to show the same front polish that removed an earlier gilded surface,

(C) Antiquity Publications Ltd, 2017 
thus providing potential directions for future research. This technical observation would be consistent with previous research that has highlighted a legacy of Quimbaya styles in the gold-making traditions of northern Colombia (Cooke \& Bray 1985; Falchetti 1987, 1995; Bray 1992). Reddish hues are also used, although not exclusively, by the Zenúthe other notable gold-working tradition near the Caribbean coast of Colombia (Figure 1). Interestingly, female representations are abundant in Zenú and Early Quimbaya material culture (Sáenz-Samper 1993; Falchetti 1995), where connections between metalwork and the female have also been proposed (Uribe-Villegas 2005). Farther north, a preference for copper-rich gold alloys has been documented among the Taíno societies of the Greater Antilles. They called this metal guanin and were attracted by its supernatural associations, which materialised in a unique smell, reddish or purple colour, shiny quality and possible foreign origin. Guanín's qualities contrasted to the paleness and lack of odour of local gold (Bray 1997; Oliver 2000; Martinón-Torres et al. 2007; Valcárcel Rojas \& MartinónTorres 2013). In the Cuban cemetery of El Chorro de Maíta, an indigenous female buried sometime after the conquest was accompanied by several guanín objects, including what seems to be a Tairona bird, probably transported by Europeans along with Colombian loot. This is the only object in the assemblage with evidence of depletion gilding and, as with the Nahuange objects, the golden layer appears to have been deliberately polished off (Martinón-Torres et al. 2012). Future work could, therefore, focus on the ethnography of colours and sheens (beyond metals), and possible associations with female and passage rites, with a particular focus on the Circum-Caribbean region. Furthermore, notwithstanding the frequent challenge of poor contextual data, future research should continue to study the diachronic development of gold-working traditions, trying to overcome oversimplified, atemporal narratives.

Finally, this study of Nahuange gold work emphasises not only the active role of social agents in adopting, adapting or rejecting innovations, but also the need to prove intentionality behind the actions recorded in archaeological material culture. While the removal of gilded layers among the Nahuange denotes a purposeful act, the intentionality behind depletion gilding in hammered and annealed gold-alloy artefacts, here or elsewhere, cannot be assumed. In gilded cast objects, if post-depositional treatments can be excluded, surface depletion is more probably the result of an intentional act (but see Martinón-Torres \& Uribe-Villegas (2015: 144-45) for tumbaga cast figurines accidentally depleted-gilded by burning). The gilding of hammered tumbaga items may, however, have been simply unavoidable, irrespective of the intentions and expectations of goldsmiths and consumers. This should not only raise caution in South American contexts, but also in other regions where depletion gilding has been identified by archaeometallurgists.

\section{Acknowledgements}

This work was initiated as part of an MSc dissertation by Sáenz-Samper at the UCL Institute of Archaeology, with support from the Museo del Oro and the Banco de la República de Colombia. It was then continued with support from a Research Catalyst Award from Santander Universities to Martinón-Torres. We are very grateful to the extremely supportive staff at the Museo del Oro, particularly María Alicia Uribe-Villegas, Robert Rubio, Orlando Castillo, Jessica Perez and Clark Manuel Rodríguez, as well as to colleagues in London, including Kevin Reeves, Matt Phelps, Loic Boscher and Siran Liu. 


\section{Supplementary material}

To view supplementary material for this article, please visit https://doi.org/10.15184/aqy. 2017.97

\section{References}

Bischof, H, 1969. Contribuciones a la cronología de la Cultura Tairona (Sierra Nevada de Santa Marta), in Proceedings of the $38^{\text {th }}$ International Congress of Americanists, Stuttgart: 271-80. Munich: Kommissionsverlag Klaus Renner.

BLAKELOCK, E.S. 2016. Never judge a gold object by its surface analysis: a study of surface phenomena in a selection of gold objects from the Staffordshire Hoard. Archaeometry 58: 912-29. https://doi.org/10.1111/arcm.12209

Bray, W. 1990. Cruzando el tapón del Darién: una visión de la arqueología del Istmo desde la perspectiva colombina. Boletín Museo del Oro 29: $2-51$.

- 1992. Sitio Conte. Metalwork in its Pan-American context, in P. Hearne \& R. Sharer (ed.) River of Gold. Precolumbian treasures from Sitio Conte: 33-36. Philadelphia: University of Pennsylvania Museum of Archaeology and Anthropology.

- 1997. Metallurgy and anthropology: two studies from Prehispanic America. Boletín Museo del Oro 42: 37-55.

- 2003. Gold, stone and ideology: symbols of power in the Tairona tradition, in J. Quilter \& J.W. Hoopes (ed.) Gold and power in ancient Costa Rica, Panama, and Colombia: 301-44. Washington, D.C.:

Dumbarton Oaks Research Library and Collection.

Bronk Ramsey, C. 2009. Bayesian analysis of radiocarbon dates. Radiocarbon 51: 337-60. https://doi.org/10.1017/S0033822200033865

Cooke, R.G. \& W. Bray. 1985. The goldwork of Panama: an iconographic and chronological perspective, in J. Jones (ed.) The art of Precolumbian gold: the Jan Mitchell Collection: 35-45. London: Weidenfeld \& Nicolson.

Falchetti, A. 1987. Desarrollo de la orfebrería Tairona en la provincia metalúrgica del norte colombiano. Boletín Museo del Oro 19: 3-23.

- 1993. La tierra del oro y el cobre: parentesco e intercambioentre comunidades orfebres del norte de Colombia y áreas relacionadas. Boletín Museo del Oro 34-35: 3-76.

- 1995. El oro del gran Zenú. Metalurgia prehispánica en las llanuras del Caribe colombiano. Bogotá: Colección Bibliográfica Banco de la República.

- 1999. El poder simbólico de los metales: la tumbaga y las transformaciones metalúrgicas. Boletín de Arqueología 14(2): 53-82.
- 2003. The seed of life: the symbolic power of gold-copper alloys and metallurgical transformations, in J. Quilter \& J.W. Hoopes (ed.) Gold and power in ancient Costa Rica, Panama, and Colombia: 345-81. Washington, D.C.: Dumbarton Oaks Research Library and Collection.

Gigante, G.E., P. Ricciardi \& S. Ridolfi. 2005. Areas and limits of employment of portable EDXRF equipment for in situ investigations. ArcheoSciences, Revue d'Archéométrie 29: 51-59.

Giraldo, S. 2010. Lords of the snowy ranges: politics, place, and landscape transformation in two Tairona towns in the Sierra Nevada de Santa Marta, Colombia. Unpublished PhD dissertation, University of Chicago.

GonzÁlez, L. 2004. Bronces sin nombre. La metalurgia prehispánica en el Noroeste argentino. Buenos Aires: Fundación CEPPA.

Hörz, G. \& M. Kallfas. 2000. The treasure of gold and silver artifacts from the Royal Tombs of Sipán, Peru-a study on the Moche metalworking techniques. Materials Characterization 45: 391-419. https://doi.org/10.1016/S1044-5803(00)00093-0

La Niece, S. \& N. Meeks. 2000. Diversity of goldsmithing traditions in the Americas and the Old World, in C. McEwan (ed.) Precolumbian gold: technology, style and iconography: 220-39. London: British Museum.

LANGEBAeK, C. 1987. La cronología de la región Tairona vista desde Papare, Municipio de Ciénaga. Boletín de Arqueología. Fundación de Investigaciones Arqueológicas Nacionales 2(1): 85-104.

- 2005. The Prehispanic population of the Santa Marta Bays. A contribution to the study of the development of the northern Colombia Tairona chiefdoms. Pittsburgh (PA): Universidad de los Andes-University of Pittsburgh Latin American Archaeology.

Lechtman, H. 1973. The gilding of metals in pre-Columbian Peru, in W. Young (ed.) Application of science in examination of works of art: 38-52. Boston (MA): Museum of Fine Arts.

- 1977. Style in technology: some early thoughts, in H. Lechtman \& R.S. Merril (ed.) Material culture: styles, organization, and dynamics of technology: 3-20. New York: West.

- 1984. Andean value systems and the development of Prehispanic metallurgy. Technology and Culture 25: 1-36. https://doi.org/10.2307/3104667 


\section{Depletion gilding, innovation and life-histories}

- 1988. Traditions and styles in Central Andean metalworking, in R. Maddin (ed.) The beginnings of the use of metals and alloys: 344-78. Cambridge (MA): MIT.

Martinón-Torres, M. \& M. URibe-Villegas. 2015. The prehistoric individual, connoisseurship and archaeological science: the Muisca goldwork of Colombia. Journal of Archaeological Science 63: 136-55. https://doi.org/10.1016/j.jas.2015.08.014

Martinón-Torres, M., R. Valcárcel Rojas, J. Cooper \& Th. Rehren. 2007. Metals, microanalysis and meaning: a study of metal objects excavated from the indigenous cemetery of $\mathrm{El}$ Chorro de Maíta, Cuba. Journal of Archaeological Science 34: 194-204. https://doi.org/10.1016/j.jas.2006.04.013

Martinón-Torres, M., R. VAlcárcel Rojas, J. Sáenz-Samper \& M. Guerra. 2012. Metallic encounters in Cuba: the technology, exchange and meaning of metals before and after Columbus. Journal of Anthropological Archaeology 31: 439-54. https://doi.org/10.1016/j.jaa.2012.03.006

Mason, J.A. 1931. Archaeology of Santa Marta Colombia. The Tairona culture. Part I: report on field work (Field Museum of Natural History, Anthropological Series 20(1)). Chicago (IL): Field Museum.

- 1936. Archaeology of Santa Marta Colombia. The Tairona culture. Part II, section I: objects of stone, shell, bone and metal (Field Museum of Natural History, Anthropological Series 20(2)). Chicago (IL): Field Museum.

- 1939. Archaeology of Santa Marta Colombia. The Tairona culture. Part II, section II: objects of pottery (Field Museum of Natural History, Anthropological Series 20(3)). Chicago (IL): Field Museum.

Oliver, J.R. 2000. Gold symbolism among Caribbean chiefdoms: of feathers, çibas and guanín power among Taíno elites, in C. McEwan (ed.) Pre-Columbian gold in South America: technology, style and iconography: 196-219. London: British Museum.

Oyuela- Caycedo, A. 1987. Implicaciones de las secuencias locales y regionales en los aspectos culturales de los Tairona, in R. Drennan \& C. Uribe (ed.) Chiefdoms of the Americas: 213-30. Lanham (MD): University Press of America.

Plazas, C. 2007. Vuelo nocturno. El murciélago prehispánico del Istmo centroamericano y su comparación con el murciélago Tairona. Bogotá: Fundación de Investigaciones Arqueológicas Nacionales (FIAN) \& Banco de la República.
Reichel-Dolmatoff, G. 1981. Things of beauty replete with meaning. Metals and crystals in Colombian Indian cosmology, in Sweat of the sun and tears of the moon: gold and emerald treasures of Colombia: 17-33. Los Angeles (CA): Natural History Museum of Los Angeles County.

Reimer, P.J., E. Bard, A. Bayliss, J.W. Beck, P.G. Blackwell, C. Bronk Ramsey, C.E. Buck, H. Cheng, R.L. Edwards, M. Friedrich, P.M. Grootes, T.P. Guilderson, H. Haflidason, I. Hajdas, C. Hatté, T.J. Heaton, D.L. Hoffmann, A.G. Hogg, K.A. Hughen, K.F. Kaiser, B. Kromer, S.W. Manning, M. Niu, R.W. Reimer, D.A. Richards, E.M. ScotT, J.R. Southon, R.A. Staff, C.S.M. Turney \& J. van Der Plicht. 2013. IntCal13 and Marine13 radiocarbon age calibration curves $0-50,000$ years cal BP. Radiocarbon 55: 1869-87. https://doi.org/10.2458/azu_js_rc.55.16947

SÁENZ-SAMPER, J. 1993. Mujeres de barro: estudio de las figuras de barro de Montelíbano. Boletín Museo del Oro 34-35: 77-110.

- 2015. Inscrito en metal. Tecnología metalúrgica en la Sierra Nevada de Santa Marta, Colombia. Bogotá: Fundación de Investigaciones Arqueológicas Nacionales (FIAN) \& Banco de la República.

Schlosser, S., A. Reinecke, R. Schwab, E. Pernicka, S. Sonetra \& V. Laychour. 2012. Early Cambodian gold and silver from Prohear: composition, trace elements and gilding. Journal of Archaeological Science 39: 2877-87. https://doi.org/10.1016/j.jas.2012.04.045

ScotT, D. 1983. Depletion gilding and surface treatment of gold alloys from the Nariño area of ancient Colombia. Historical Metallurgy 17: 99-115.

Troalen, L.G., J. Tate \& M.F. Guerra. 2014. Goldwork in ancient Egypt: workshop practices at Qurneh in the $2^{\text {nd }}$ Intermediate Period. Journal of Archaeological Science 50: 219-26. https://doi.org/10.1016/j.jas.2014.07.010

Uribe-Villegas, M. 2005. Mujeres, calabazos, brillo y tumbaga. Símbolos de vida y transformación en la orfebrería Quimbaya Temprano. Boletín de Antropología Universidad de Antioquia 19(36): 61-93.

Valcárcel Rojas, R. \& M. Martinón-Torres. 2013. Metals in the indigenous societies of the Caribbean, in W.F. Keegan, C.L. Hofman \& R. Rodríguez Ramos (ed.) The Oxford handbook of Caribbean archaeology: 504-22. Oxford: Oxford University Press.

Received: 7 June 2016; Accepted: 16 September 2016; Revised: 1 November 2016

(C) Antiquity Publications Ltd, 2017 